\title{
Online Group Purchasing Environment, the Effects of Price Discounts and
}

\section{Crowd Psychology on Purchasing Behavior}

\author{
Muhammad Qomarul Huda ${ }^{1, *}$, A'ang Subiyakto ${ }^{2}$, Aedah Abd. Rahman ${ }^{3}$ \\ ${ }^{1,2}$ Department of Information Systems, UIN Syarif Hidayatullah Jakarta, Indonesia \\ ${ }^{3}$ School of Science and Technology, Asia e University, Malaysia \\ ${ }^{1}$ mqomarul@uinjkt.ac.id*; ${ }^{2}$ aang_subiyakto@uinjkt.ac.id; ${ }^{3}$ aedah.abdrahman@aeu.edu.my \\ * corresponding author
}

(Received: August 8, 2021; Revised: August 22, 2021; Accepted: October 12, 2021; Available online: December 1, 2021)

\begin{abstract}
The goal of this study is to determine the influence of impulsive purchase behavior on mobile marketing, discounts, and consumer lifestyle. The approach used is a combination of quantitative research and an explanation survey. The population for this study is comprised of active internet users who have completed marketplace transactions. The dataset was sampled in a non-probabilistic manner (convenience sampling) and included data from 100 respondents. The results suggested that mobile marketing and promotions had no obvious influence on impulsive purchases made by marketplace customers. Meanwhile, lifestyle has a good influence on the impulsive purchase behavior of marketplace consumers by 35.1 percent. Mobile marketing, incentives, and lifestyle all have a combined influence on the marketplace of 20.9 percent on impulse purchases. While the remaining 79.1 percent is impacted by elements that have not been investigated. This research was conducted using earlier studies as a baseline against which to establish the hypothesis for each variable. The study's design was quantitative, with an emphasis on explanatory research. Convenience sampling was used in this study. This study was successful in determining the effects and interactions associated with impulse purchasing. Discounts, lifestyle, and mobile marketing are integrated and analyzed to see which aspects have the biggest influence.
\end{abstract}

Keywords: Impulse Buying; Marketing; Mobile Marketing; Convenience Sampling

\section{Introduction}

A market is a network of interactions and relationships that facilitate the exchange of information, goods, services, and money. When many people embraced the internet market, the business center ceased to be a physical structure but a specialized site or platform on the network where commercial contacts occur, a practice known as electronic marketing [1]. Electronic marketing (E-Marketing) is a subset of e-commerce, and as customer demands for convenience and personalisation increase, e-marketing is rapidly evolving into mobile marketing (M-Marketing). Mobile marketing, often known as mobile advertising, is the practice of advertising using mobile devices such as smartphones and tablets. Initially, it was anticipated that purchasing and selling activities on the internet, particularly on mobile devices, would change consumer behavior toward logical purchase decisions [3]. This is because mobile internet is efficient and has a range of information, which enables consumers to more easily compare costs and information about a product or service [4].

E-commerce has proven immensely successful in developed nations, generating significant economic and social advantages; nevertheless, the picture is considerably different in developing countries. Numerous obstacles in this economy have stymied e-progress. commerce's Several studies, such those by Kimiagari and Asadi [1], demonstrate that customers in industrialized nations have grown acclimated to using the Internet and have profited from e-commerce, thereby altering their lifestyles. In comparison, consumers in underdeveloped nations are accustomed to face-to-face transactions, lack trust in technological processes, and are unable to bear the associated risks. Consumers are expected to apply logic and reasoning to make purchases from there. However, not all buyers make sensible and logical decisions when making internet purchases. As a result, the phenomena of impulse buying developed. Impulse 
purchasing or impulsive buying sometimes happens without prior thought or preparation. Apart from transactional simplicity, which is a component of service stimuli, another factor that might contribute to impulsive purchases is marketing stimulation in the form of promotional activities. Discounts are one strategy to increase sales. This circumstance highlights the crucial nature of understanding the critical factors that motivate customers in developing countries to adopt e-commerce in order to gain the economic and social benefits enjoyed by developed countries. The approach suggested in this study analyses and differentiates the critical components of purchasing intention.

\section{Literature Review}

\subsection{Mobile Marketing}

Leppäniemi et al. [5] conducted a study of all previous studies on mobile marketing and developed their own definition of mobile marketing. According to the author, "mobile marketing" is defined as "the use of mobile media for marketing communication." This term encompasses the following aspects of marketing communications: communication that is one-way or interactive; at least one communication party that uses a mobile/mobile device [6]; at least one communication party that benefits monetarily from the communication. The Mobile Marketing Association (MMA) defines mobile marketing as "a set of activities that enables businesses to communicate and engage with their consumers in a relevant and engaging manner via any mobile device or network" [7]. Specific characteristics of mobile channels can be highlighted to show the benefits of marketing communications via mobile devices. Wireless devices are neither location- or time-bound; they are portable and accessible at any time [8]. Because cellular channels are "immediate" and "customized," the key benefit is mobility, which enables users to get information regardless of their location or time of day.

\subsection{Discount}

According to Fu et al., [9] price discounts are savings offered to consumers from the normal price of a product, which is listed on the label or product packaging. Belch [10] explains that the promotion of discounted prices provides several benefits, including: it can trigger consumers to buy in large quantities, anticipate competitors' promotions, and support trade in larger quantities. Discounted prices are popular because they directly encourage consumers to purchase the offered goods, resulting in increased sales. According to Zhu et al. [11], a price discount is a drop in the price of a product relative to its regular price over a specified time period. The discount indicators are as follows: 1) The discount amount, which is the amount deducted from the price of a product when it is discounted. 2) The discount term, which is the time period stated at the time of the discount, and 3) The items that are qualified for the discount, more precisely the range of discounted products.

\subsection{Lifestyle}

According to Mehta and Anand [12], lifestyle is a way of existence in the world manifested by an individual's activities, interests, and attitudes. Consumers who live a hedonic lifestyle frequently make purchasing decisions based on emotional rather than rational reasons. A person's lifestyle is revealed through his actions, interests, and opinions in the world [13]. The phrase "lifestyle" refers to a group of people who interact with their surroundings. Additionally, each individual possesses distinct personality characteristics that impact their purchasing decisions. Typically, personality is defined by characteristics such as self-confidence, dominance, autonomy, respectability, social skills, self-defense, and adaptability. Meanwhile, Yang et al. [7] describe lifestyle as a manner of life dictated by psychographic characteristics. Psychographics is the process of establishing the major AIO aspects of a consumer: Activities, Interests, and Opinions.

\subsection{Impulse Buying}

Impulse purchasing is described as non-planned purchasing that occurs as a result of exposure to a stimulus and is made on the spot. Consumers will suffer emotional and cognitive emotions following a purchase. In other terms, impulsive purchasing can be defined as a purchase decision made by consumers without prior planning or intention to purchase. According to Phau and Lo [14], impulse buying is described as a purchasing process that is not guided by a purchase plan and typically occurs when an impulse or stimulation is triggered by a desire for something apparent at 
the time [15]. Consumers typically have an emotional or cognitive reaction to a purchase. According to this definition, impulse buying has four primary characteristics: it is unplanned, immediate, emotional and/or cognitive reaction, and exposure to the stimuli.

\section{Research Method}

Intention to purchase can be used to assess the viability of establishing new distribution channels, supporting managers in assessing if the concept warrants further development and which geographic regions and consumer categories to target via such channels. Their significance stems from the fact that intentions are widely regarded as a significant predictor of actual conduct. As a result, their research is critical to the success of any online business. This study seeks to analyze buying intention as a critical variable. The construct is applied during the hypothesis testing stage and captures the psychological factors influencing customer behavior. To forecast customer behavior, one must first understand the attitudes, judgments, and internal elements that contribute to purchase intentions. According to Kimiagari and Asadi [1] online purchase intention is defined in this study as consumers' willingness to acquire a product via an online retailer. The conceptual framework is structured as follows in light of this description:

According to Barwise and Strong [16], a survey of teenage customers revealed that "mobile marketing is an effective medium for advertising low-cost products." They discuss numerous of the factors that marketers must consider. To begin, there is the possibility of attracting the attention of customers. This indicates that mobile marketing is a great platform for advertising low-cost items in Indonesian. According to the poll, they (young consumers) highlight a variety of demands that marketers may satisfy, the most prominent of which is the desire to catch customers' attention. In conclusion, mobile marketing is the most effective method of attracting consumers' attention. Additionally, Bucht \& Gillberg [17] state that "In-app advertisements are another form of advertising on mobile platforms, and they can take the shape of banner pop-ups, full-page picture ads, or video advertisements." Consumers are immediately sent to the web store, where the product is marketed, making impulse purchases simpler". This explains why mobile applications contain numerous advertisements (ads) of various forms, such as pop-up ads and video advertisements. Customers will be led directly to the web store and the advertised goods upon clicking on the advertising, which makes it easier for consumers to make impulse purchases. According to the theories described above, mobile marketing is an effective approach to capturing consumers' attention. Consumers' willingness to make purchases, especially impulse purchases, may be raised by mobile marketing features that make finding desired items simpler.

H1. Mobile marketing has a good and considerable effect on marketplace consumers' impulse buying behavior.

Belch [10] asserts that discounted prices provide a number of advantages, including the ability to encourage consumers to buy in quantity, anticipate competitors' promotions, and facilitate larger-scale trade. Consumers want discounts because they lessen their losses when a product's price is reduced directly. Discounts are a popular pricing strategy since they encourage direct purchase of the marketed goods, which results in greater sales. According to Park [18], impulsive purchases frequently occur unexpectedly, swiftly, and spontaneously, are more emotional than rational, are frequently viewed negatively than positively, and customers frequently feel out of control when making impulsive purchases. According to Weinstein et al. [19] research the tendency of consumers to buy out of control is triggered by sales promotion stimulants, one of which being price reductions or discounts. Price discounts in a marketplace can stimulate spontaneous purchases. This is consistent with earlier research, which indicates that some customers make unplanned purchases when goods or product items are discounted [20,21]. As a result, many consumers who purchase immediately recall the benefits of this deal.

H2. Discounts have a positive and considerable effect on marketplace consumers' spontaneous buying behavior.

Improving service quality can ultimately result in increased trust, which increases the relationship's quality. Numerous research, including one by Dukas et al. [22], indicated similar findings, namely that the Lifestyle variable had a strong positive effect on impulse purchase. According to the findings of lifestyle research on impulsive buying inclinations, it can be concluded that the more hedonistic or affluent a person's lifestyle is, the more likely and encouraged impulse buying tendencies are. According to this view, an individual's Lifestyle is determined by his or her Activities, Interests, and Opinions. That is, certain activities, interests, and attitudes held by the buyer play a role 
in deciding his willingness to make a purchase. A person's typical lifestyle has a significant impact on the occurrence of impulse purchases. This is demonstrated, for example, by consumers' proclivity to enjoy activities associated with their hobbies, such as fashion, and to have specific tastes, interests, and opinions about fashion, which results in their proclivity to make unexpected purchases of fashion items on the market. The researcher intends to test the following hypotheses based on the results of the literature review indicated above:

H3. Lifestyle has a good and substantial influence on the impulse buying behavior of Marketplace users.

Numerous investigations on the partial influence of each independent variable on the dependent variable have been undertaken by researchers in the same field. The combined influence of mobile marketing, discounts, and lifestyle on impulsive purchase behavior, on the other hand, is still in its infancy. No national or international publication has published the findings of a research on the link between these four factors prior to the time of writing this thesis. Numerous studies have demonstrated that mobile marketing has a significant positive influence on impulsive purchase behavior, as well as on the Discount and Lifestyle factors. These three variables all have the potential for a significant positive effect, implying that mobile marketing, discounting, and lifestyle all play a role in the establishment of impulse purchase behavior.

H4. Mobile marketing, discounts, and lifestyle have a good and significant effect on Marketplace users' impulsive purchasing behavior.

\section{Results and Discussion}

This study strategy is quantitative in nature and is of the explanatory variety. The population for this study is composed entirely of marketplace users drawn from the information available on Datahub. As a result, the total population of this study is unknown. This study's sample size was established using Izenman [23] theory. The sample size was established to be 25 times the number of variables in multivariate research (including those involving multivariate regression analysis). An adequate sample size of 100 respondents is required for regression analysis with four variables. After establishing the sample size, the number of responders is determined using the following criteria: 1) Respondents supply accurate information. 2) Respondents are students who use popular Indonesian marketplaces such as Amazon, Alibaba, Shopee, and Wish. 3) Respondents have made active purchases in the marketplace. Convenience sampling was used in this study.

The research respondents are marketplace users drawn from a dataset we obtained on Datahub. The dataset contains information about the respondents' gender, age, shopping frequency, frequently purchased product categories, and the marketplaces they frequent. Table 1 summarizes the results of the study's description of the respondents' characteristics.

Table. 1. Participants Attributes

\begin{tabular}{|l|l|c|c|}
\hline \multicolumn{2}{|c|}{ Respondents Characteristics } & Frequency & Percentage \\
\hline \multirow{4}{*}{ Gender } & Male & 35 & 35 \\
\cline { 2 - 4 } & Female & 65 & 65 \\
\cline { 2 - 4 } & Total & 100 & 100 \\
\hline \multirow{3}{*}{ Age } & Below 20 Years old & 30 & 30 \\
\cline { 2 - 4 } & Above 20 Years old & 70 & 70 \\
\cline { 2 - 4 } & Total & 100 & 100 \\
\hline Purchasing & 1 Time & 20 & 20 \\
\hline
\end{tabular}


Huda et al / IJIIS vol. 4, no. 3, December 2021, pp 192-205

\begin{tabular}{|c|c|c|c|}
\hline & 2 Time & 15 & 15 \\
\hline & 3 Time & 5 & 5 \\
\hline & More than 3 Times & 60 & 60 \\
\hline & Total & 100 & 100 \\
\hline \multirow[t]{5}{*}{ Visited Marketplace } & Amazon & 63 & 63 \\
\hline & Alibaba & 15 & 15 \\
\hline & Shopee & 20 & 20 \\
\hline & Wish & 2 & 2 \\
\hline & Total & 100 & 100 \\
\hline \multirow[t]{16}{*}{ Product Categories } & Household Electronics & 5 & 1.94 \\
\hline & Fashion \& Accessories & 75 & 29.07 \\
\hline & Handphone \& Tablet & 8 & 3.10 \\
\hline & Watch, Glasses \& Jewelry & 28 & 10.85 \\
\hline & Camera \& Photography & 1 & 0.39 \\
\hline & Health \& Beauty & 31 & 12.01 \\
\hline & Computer \& Laptop & 6 & 2.33 \\
\hline & Toys \& Baby Equipment & 1 & 0.39 \\
\hline & Food, Drink \& Grocery & 20 & 7.75 \\
\hline & Media, Music \& Books & 27 & 10.47 \\
\hline & Sport \& Outdoor & 6 & 2.32 \\
\hline & Household Equipment & 9 & 3.48 \\
\hline & Bag \& Suitcase & 27 & 10.47 \\
\hline & Automotive & 1 & 0.39 \\
\hline & Voucher \& Services & 13 & 5.04 \\
\hline & Total & 258 & 100 \\
\hline
\end{tabular}

According to the data from the respondents' characteristics, the majority of respondents in this study were female, over the age of 20, and generally made purchases more than three times in the recent year. Ten months, covering popular categories such as Fashion \& Accessories and Health \& Beauty. Respondents are Shopee users. 


\subsection{Variables in the Research}

According to the table's explanation of respondents' replies, the average value of the Mobile marketing variable is 3.57, suggesting that the majority of respondents approve the use of mobile marketing features to facilitate and encourage spontaneous purchases. Meanwhile, based on the description of respondents' responses in Table 2, the average value of the discount variable is 4.01 , indicating that when the discount price, the discount period, and the type of discount are specified, the majority of consumers agree with the desire to shop induced by the discount variable. reduced merchandise. Additionally, the average value of the Lifestyle variable is 3.98, showing that the majority of customers concur with the desire to shop as a result of the Lifestyle variable. Meanwhile, based on the responses described in Table 2, the average value of the Impulse purchasing variable is 3.375, suggesting that the majority of consumers agree or are indifferent to the appearance of a desire to purchase as a result of market stimulation. Table 2 summarizes the findings from this study's elaboration of each indicator variable.

Table. 2. Means of Indicators and Research Variables

\begin{tabular}{|c|c|c|c|}
\hline \multirow[t]{2}{*}{ Variable } & \multirow[t]{2}{*}{ Indicators } & \multicolumn{2}{|l|}{ Mean } \\
\hline & & Indicator & Variable \\
\hline \multirow{9}{*}{$\begin{array}{l}\text { Mobile Marketing } \\
(\mathrm{MM})\end{array}$} & MM1 - SMS/MMS & 3.08 & \multirow[t]{9}{*}{3.57} \\
\hline & MM2 - Mobile Web & 4.09 & \\
\hline & MM3 - Social Media & 3.89 & \\
\hline & MM4 - Mobile Ads & 2.89 & \\
\hline & MM5 - QR Codes & 2.75 & \\
\hline & MM6 - Push Notification & 3.06 & \\
\hline & MM7 - Mobile Shopping & 4.19 & \\
\hline & MM8 - Mobile Banking & 3.98 & \\
\hline & MM9 - Mobile Tracking & 4.20 & \\
\hline \multirow[t]{3}{*}{ Discount (D) } & D1 - Discount Amount & 4.17 & \multirow[t]{3}{*}{4.01} \\
\hline & D2 - Discount Period & 3.92 & \\
\hline & D3 - Product Category & 3.95 & \\
\hline \multirow[t]{3}{*}{ Lifestyle (L) } & L1 - Activities & 4.17 & \multirow[t]{3}{*}{3.98} \\
\hline & L2 - Interest & 3.82 & \\
\hline & L3 - Opinion & 3.97 & \\
\hline \multirow{4}{*}{$\begin{array}{l}\text { Impulse Buying } \\
\text { (IB) }\end{array}$} & IB1 - Unplanned & 2.92 & \multirow[t]{4}{*}{3.375} \\
\hline & IB2 - Immediate & 3.2 & \\
\hline & IB3 - Emotional Reaction & 3.64 & \\
\hline & IB4 - Exposure to the stimulus & 3.73 & \\
\hline
\end{tabular}


According to the mean indications and variables, respondents rated the function of mobile tracking and mobile shopping in the Marketplace application at 4.20 and 4.19, respectively. Following that, the mobile web's importance was ranked 4.09, mobile banking's importance was placed 3.98, and social media's importance was ranked 3.89. While the average score for QR Code utilization is only 2.75, it is 2.89 for mobile ads. When we evaluate the actual empirical circumstances, which are determined by respondents' views of the mobile marketing variable, we find them to be quite positive. Because an increase in the advantages associated with the marketplace feature has the potential to alter the appearance of consumer impulsive purchasing behavior, it is likely to have an effect on the marketplace's profitability. Additionally, respondents' responses indicate that the Discount Price Amount has the highest average score of 4.17 for the Discount variable, followed by Product Type at 3.95 and Discount Period at 3.92. If it is witnessed under real-world empirical situations, based on the consumer's evaluation of the Discount variable, it is deemed acceptable. Because offering discounts on specific sorts of products for a limited period of time might sway consumers' preferences and push them to make purchases.

When it comes to the Lifestyle variable, respondents indicate that the Activity indicator has the highest average score of 4.17, followed by the Opinion indicator's 3.97 and the Interest indicator's 3.92. It is judged appropriate if it is observed in real-world empirical scenarios and is based on consumer perceptions of the Lifestyle component. While respondents' responses to the Impulse Buying variable suggest that the highest average score for the Exposure indication is 3.73, the Emotional Reaction indicator is 3.64, the Immediate indicator is 3.2, and the Unplanned indicator is 2.93. When real-world empirical conditions are considered, it is still scored rather well, according to the consumer's assessment of the Impulse buy variable. In other words, while Marketplace has succeeded in providing a quick and user-friendly shopping environment with discounts customized to consumers' lives, this does not guarantee that consumers would make impulse purchases.

\subsection{Evaluation of Multiple Linear Regression Analysis}

Table. 3. Coefficients

\begin{tabular}{|c|c|c|c|c|c|}
\hline \multirow[t]{2}{*}{ Model } & \multicolumn{2}{|c|}{ Standardized Coefficient } & \multirow{2}{*}{$\begin{array}{c}\text { Standardized } \\
\text { Coefficient } \\
\text { Beta }\end{array}$} & \multirow{2}{*}{$\mathrm{t}$} & \multirow{2}{*}{ Sig. } \\
\hline & $\mathrm{B}$ & Std. Error & & & \\
\hline (Constant) & 8.733 & 4.143 & & 2.108 & .038 \\
\hline $\begin{array}{l}\text { Mobile } \\
\text { Marketing }\end{array}$ & .056 & .049 & .125 & 2.133 & .026 \\
\hline Discount & .008 & .127 & .008 & 2.421 & .018 \\
\hline Lifestyle & .351 & .137 & .371 & 2.555 & .012 \\
\hline
\end{tabular}

The t-test or partial test is a statistical test used to determine if the coefficient of each independent variable, such as mobile marketing (X1), discounts (X2), or lifestyle (X3), has a significant influence on the relationship variable, such as impulsive purchase (Y) (separate). The test has a significance level of $(\alpha)=0.05$. The T test results are shown in Table 3.

Test 1 of Hypothesis 1: Mobile marketing has a positive and statistically significant influence on impulse purchasing behavior.

As the table above indicates, the $t$ test results reveal that the Mobile marketing variable has a $t$ count of 2.133 and a probability value of 0.026 . The degrees of freedom $\mathrm{df}=(\mathrm{n}-\mathrm{k}-1)$ or $100-3-1=96 \mathrm{can}$ be used to assess the table's relevance. (where $\mathrm{n}$ denotes the total number of data points and $\mathrm{k}$ denotes the total number of independent variables). The MS software may be used to do table searches. Using the Excel formula $=\operatorname{tinv}(\alpha ; \mathrm{df} 2)$ or $=\operatorname{tinv}(0.05 ; 99)$. Then 
the obtained table is 1,984 . Thus, the value of $\mathrm{t}$ count $=2.133$ can be deduced. This suggests that $\mathrm{H} 1$ is accepted, and hence that mobile marketing does have an influence on impulse purchasing behavior in the consumer market studied in this case study.

Discounts have a positive and statistically significant impact on impulsive purchase behavior. Discounts have a good and substantial influence on impulsive purchasing behavior Hypothesis 2: Discounts have a positive and significant impact on impulsive purchasing behavior.

The discount variable is calculated by multiplying $t=2.421$ by 0.18 . As a result, the value of $t$ count is 0.159 . This demonstrates that $\mathrm{H} 2$ is accepted, and hence that the discount variable does have an influence on impulsive purchasing behavior in the consumer market studied in this study.

Third Hypothesis Test: Lifestyle has a favorable and statistically significant effect on Impulsive Purchasing Behavior

With a probability value of 0.012 , lifestyle variables obtained $t$ count $=2.555$. Thus, using a significance threshold of 0.0120 .05 , it may be inferred that $\mathrm{t}$ arithmetic $=2.555>\mathrm{t}$ table $=1.984$. This suggests that $\mathrm{H} 3$ is accepted, implying that lifestyle characteristics have a positive and statistically significant effect on impulsive purchasing behavior in the consumer market. It's entirely realistic to assume that, based on the data we have, the majority of customers have made purchases more than three times; it becomes a very common and common occurrence if the customer's buy intention is substantially influenced by his or her lifestyle.

Table 4 summarizes the outcomes of hypothesis testing in general. The following table summarizes the findings of hypothesis testing about the relationship between each variable:

Table. 4. Hypothesis Test

\begin{tabular}{|l|l|l|}
\hline Hypothesis & Effect between variables & Description \\
\hline H1 & Mobile Marketing -> Impulse Buying & Accepted \\
\hline H2 & Discount -> Impulse Buying & Accepted \\
\hline H3 & Lifestyle -> Impulse Buying & Accepted \\
\hline
\end{tabular}

According to the results of the analysis in the table above, three hypotheses were accepted based on the three direct effects between the variables evaluated. F Examination Results (Simultaneous Testing) The results of the tests are listed in the table below.

Tabel. 5. ANOVA

\begin{tabular}{|l|l|l|l|l|l|}
\hline Model & Sum of Squares & df & Mean Square & F & Sig. \\
\hline Regression & 487.024 & 3 & 162.341 & 8.475 & .000 \\
\hline Residual & 1838.976 & 96 & 19.156 & & \\
\hline Total & 2326.000 & 99 & & & \\
\hline
\end{tabular}

As shown in Table 5, the computed F is 8.475 with a sig. of 0.000 . Determine the degrees of freedom initially before determining the F-table (df1 and df2). With a 5\% significance level, df1 (the df value of the regression model divided by the number of independent variables) $=3$ and $\mathrm{df} 2$ (the df values of a residual model split by nk-1), or 100-3-1= 96, (where $\mathrm{n}$ is the number of respondents and $\mathrm{k}$ is the number of independent variables). The MS software may be used to do table searches. In Excel, use the formula $=$ finv $(\mathrm{df} 1 ; \mathrm{df} 2)$ or $=$ finv $(0.05 ; 3 ; 96)$. The table has a total of 2,699 rows. 
All of these elements, including mobile marketing, discounts, and lifestyle considerations, have a positive and significant influence on impulsive purchase behavior.

With a significance threshold of 0.05 , the $\mathrm{F}$ test findings reveal that F-count $=8.475>\mathrm{F}$-table $=2.699$ suggests that $\mathrm{H} 4$ is accepted.

Table. 6. Hypothesis Test

\begin{tabular}{|c|c|c|}
\hline Hypothesis & Effects between variables & Description \\
\hline H4 & $\begin{array}{l}\text { Mobile marketing, Discount, } \\
\text { Lifestyle -> Impulse Buying }\end{array}$ & Accepted \\
\hline
\end{tabular}

In table 6 above, the fourth hypothesis shows that mobile marketing, discounts and lifestyle are accepted as one of the driving factors for impulse buying.

The primary element influencing customers' spontaneous purchases is lifestyle variables. The numbers above illustrate that lifestyle influences impulsive purchasing behavior significantly, since customers are more likely to make impulse purchases. When shoppers are driven by hedonic or economic motives such as pleasure, fantasy, social or emotional satisfaction, and the shopping experience is designed to satisfy the demands of a hedonic lifestyle, the things they purchase appear to be picked spontaneously and provide an impulsive purchasing event.

Next is the promotion factor or in general discounts that affect impulse buying is also an important factor in increasing impulse buying. This is because the promotion is carried out, the greater the chance that the customer will make a purchase. Promotions are generally carried out in the form of giving discounts, providing clear explanations. Interesting information about the product, an attractive arrangement and the right information about the products offered, so that consumers are interested in buying the products offered even though consumers do not plan to buy the product beforehand.

The third factor that is able to influence impulse buying on consumers is the mobile marketing factor, with the existence of mobile marketing customers will be given convenience in making purchases. This also plays an important role in media marketing, because with a mobile marketing customer does not have to worry about the availability of goods and the distance between the seller and the buyer. As a consequence, it can be concluded that mobile marketing, discounts, and lifestyle all have a favorable and significant impact on impulse purchases in the consumer market studied in this study. Multiple Correlation Test Results (R) The following table summarizes the multiple correlation analysis findings:

Table. 7. Model Summary

\begin{tabular}{|c|c|c|c|c|}
\hline Model & R & R Square & Adjusted R Square & $\begin{array}{c}\text { Std. Error of the } \\
\text { Estimate }\end{array}$ \\
\hline 1 & .458 & .209 & .185 & 4.37676 \\
\hline
\end{tabular}

As seen in the summary model table above, the $\mathrm{R}$ value is 0.458 . This indicates a 0.458 correlation between mobile marketing, discounts, lifestyle traits, and impulse purchases. This indicates that mobile marketing, discounts, and lifestyle have a moderate impact on impulsive purchases. The Adjusted $\mathrm{R}^{2}$ (R Square) value is 0.209 or 20.9 percent, as shown in Table 7 of the prior model. This implies that mobile marketing, discounts, and lifestyle influence 20.9 percent of impulse purchases. While the remaining 79.1 percent is impacted by elements that have not been investigated. 


\subsection{Discussion}

Consumers express satisfaction with the outcomes of the description of consumer responses to the use of mobile marketing features. However, the fact is that extensive usage of mobile marketing features is insufficient to raise customers' spontaneous purchases in general. This is evidenced by the fact that 27.2 percent of customers say that existing mobile marketing indicators are insufficient. Mobile tracking is the most crucial indication perceived by customers, according to the analysis's mean score. This indicates that the marketplace has earned customer trust in the marketplace's security and openness regarding the tracking procedure from the seller's warehouse to the consumer's hand. Additionally, customer impressions of mobile shopping (application) are good in instances where the Marketplace has facilitated access for the majority of consumers, resulting in a user-friendly or user-friendly environment for them to visit and purchase. Numerous components are regarded insufficient by customers, including the usage of QR Codes and mobile adverts, which are deemed incapable of generating the necessary degree of excitement. This might be because customers haven't grasped or are unfamiliar with specific functions. In light of these conditions, the marketplace must make substantial efforts to enhance its capacity to provide intriguing information in a more convenient and user-friendly way or via a more user-friendly medium.

The study's findings indicate that mobile marketing has no obvious influence on impulsive purchases. According to the survey, the typical internet user is above the age of 20 , and the most often conducted commercial activity is online shopping; as a result, it is anticipated that the marketplace via mobile marketing would be the suitable facility to increase impulsive buying. This does not, however, ensure that marketplace shoppers will make a quick purchase. Students may be considered as consumers who do not have a fixed income. As a result, mobile marketing campaigns have proven unable to influence customers' willingness to make impulsive purchases. In other words, the majority of respondents are still deliberating on the best moment and opportunity to make an unanticipated and unexpected purchase. Given the study's findings that mobile marketing had no significant influence on spontaneous purchases, this corroborates Mahalakshmi [24] notion that mobile marketing strategies are not always well received by customers. He established that mobile marketing is a highly adaptive strategy that is less expensive than traditional marketing strategies $[25,26]$. However, in certain instances, such as when utilizing the SMS/MMS function, if the information supplied is counter to the recipient's preferences or tastes (SMS/MMS recipient), the technique will be termed 'disturbing' since it is unrelated to what consumers desire. This is consistent with the study's findings, which reveal that a variety of features, such as SMS/MMS, Push Notifications, QR Codes, and mobile adverts provide a plethora of information and promotional content but are of little utility or relevance to clients. The poor response rates to these characteristics attest to this [27]. Thus, while other indicators related to mobile applications have been demonstrated to influence impulse purchases, the existence of indicators with such low values might impair the overall results of the research variables.

Turkyilmaz et al., [28] also identified elements that influence impulse buying via mobile marketing, including psychological considerations, time availability, and resource availability (money availability). When adjusted for the characteristics of the respondents in this study, who are students aged 15-24 years, it can be concluded that they are psychologically mature enough to make purchasing decisions but not yet capable in terms of time availability and resource availability [29]. Given their status as students with busy schedules and no permanent income, they prefer to make scheduled purchases as needed rather than impulsive or unplanned purchases. Wang [30] discovered that shopping via mobile had a beneficial but not statistically significant influence on impulsive purchasing behavior. Additionally, Wang demonstrates that, while impulse buying behavior is more prevalent in the world of cellular purchases, the idea is not validated (accepted) by his research findings. Additionally, he mentioned that in the future, mobile marketing research on impulse buying will be conducted directly after customers make purchases via mobile, allowing consumers to quickly recall and recognize their impulsive behavior [31]. This is because impulse buying is immediate (impromptu), and hence cannot be identified over a long period of time. Additionally, it is known from the findings of the SPSS multiple linear regression test that discounts have no significant effect on impulse purchases [32]. The rationale and theory underlying the ability of discounts to induce consumers to make unplanned purchases at offline retail appear to yield different outcomes when seen against the backdrop of internet retail, specifically mobile (mobile settings) in the marketplace. 
While the discount is designed to entice shoppers to make an instant purchase, this is not always the case in the case of an online marketplace. The discount variable has no influence on the impulsive purchase variable in this study because consumers are not thinking about discounts when they visit the marketplace; so, buyers want to open apps to explore items or visit and shop without thinking about discounts. Customers have high expectations for their emotional reactions to the size of the discount price signal, but their readiness to make an unplanned and sudden purchase is extremely low on both the unplanned and impulsive purchasing factors. In other words, purchasers will merely come, but their urge to spend impulsively in the marketplace will stay the same regardless of whether they obtain a discount. Additionally, the findings from the description of respondents' characteristics in terms of purchasing frequency reveal that $50 \%$ or half of respondents made at least three transactions in the marketplace in the previous ten months. This suggests that people will continue to buy regardless of whether they obtain a discount.

Another reason why the discount variable has no effect on impulse purchases is due to the sort of product or discount period that is advertised in the marketplace. Consumers may appreciate the magnitude of the reduction [33,34], but if the goods being discounted is not what they require, they are discouraged from making a purchase. Additionally, consumers may be attracted to and urged to make purchases due to a favorable discount price and the sort of product required, but the discount duration is insufficient. In other words, offering adequate discounts is insufficient to entice buyers to make an immediate purchase. Additionally, marketplaces must offer discounts on particular sorts of products that are relevant to consumer demands at specific times based on consumer opportunities. Thus, in the context of online retail, future research is likely to demonstrate that discounts have a favorable and significant effect on impulse buying behavior. Referring to the study's findings that discounts had no substantial effect on impulse purchases, this is consistent with Sung and Huddleson [33] research, which indicates that discounts in both offline and online shopping do not always attract impulse buyers. He showed that offering customers more aggressive discounts does not ensure a purchase. Madhavaram and Laverie [35] conducted a similar study and concluded that the discount variable had no and no significant influence on impulse purchase. According to his research, numerous students who became respondents believed that the greater the discount granted, the higher the price set before the discount was. Thus preventing students from engaging in impulsive purchasing behavior.

The study's findings support the hypothesis that certain consumers do not immediately interpret the stimulus they receive as a bargain, simply because they are impulsive consumers. On the other hand, they [36-38] regard discounts as a marketing ploy employed by merchants to entice buyers with prices that have been increased from the standard price first. The analysis's findings indicate that the three indicators with good categories accurately reflect the marketplace's lifestyle characteristics. According to the analysis's mean score, activity is the most important indicator noticed by consumers. This means that the marketplace has created a space for people to shop based on their preferred lifestyle activities. Marketplace has facilitated consumers' purchasing experience to the point where their activities become what they enjoy and inspire them to make impulse purchases. Additionally, customer evaluations of Opinions and Interests are considered good when the Marketplace provides sufficient buying options for the majority of consumers, allowing them to make selections based on their opinions and generate interest.

According to the SPSS multiple linear regression test results, lifestyle has a significant impact on impulse purchases. The research found that the average internet user engages in the most common commercial activities, including online buying. As a result, the marketplace has supplied the necessary tools to enhance impulse buying. According to surveys and theoretical studies, customers' lifestyles can affect them to become impulsive buyers corroborate the findings of this study. As a result, the marketplace's approach has been able to impact consumers' actions, interests, and opinions, leading to unanticipated purchases. This condition demonstrates that the more affluent a consumer's lifestyle is, the stronger the consumer's desire to satisfy a demand for a product that has become a part of their lifestyle. Thus, it relates to the study's predisposition for the emergence of impulse purchase behavior. In light of the study's findings that lifestyle has a large effect on impulse buying, this is consistent with Lee [39] research, which indicates that lifestyle has a significant positive effect on impulsive buying behavior as a result of fashion engagement.

He references Guenzi et al. [40] in his research, who discovered that "engagement in fashion (such as clothing) is strongly associated with personal qualities (i.e. women and youth) and fashion expertise, which increases consumer 
confidence in purchase decisions." Consumers with a strong interest in fashion are more sensitive to being influenced by stimuli and making spontaneous purchases. The research findings are closely related to this investigation's conclusions. According to respondents, the majority of consumers are above the age of 20 (70 percent, 70 persons) and female (65 percent, 65 individuals), with fashion and accessories being the most often purchased product categories $(75$ items). This illustrates that young people, particularly the women surveyed, are predominantly engaged in fashion-related activities and possess a diverse variety of interests and viewpoints. About fashion, in helping everyday activities, such that their taste or interest in fashion items is one of the reasons lifestyle has a positive and substantial influence on impulse purchase behavior in this study. Additionally, the $\mathrm{F}$ value is 8.475 , as established by the $\mathrm{F}$ test or simultaneous test results. With a $\mathrm{F}$ table value of 2.699 . Thus, $\mathrm{H} 4$ is allowed if $\mathrm{F}$ count $>\mathrm{F}$ table. Thus, one might claim that mobile marketing programs, discounts, and lifestyles all contribute to the consumer market's impulsive buying (simultaneously).

Finally, based on the results of various correlation tests, the degree of effect strength (R) of mobile marketing, discounts, and lifestyle features on impulse purchase is 0.458 . The determination test results yielded an $R^{2}$ ( $R$ Square) of 0.209. According to these results, the effect of mobile marketing, discounts, and lifestyle influences on impulsive purchase is minimal, at 20.9 percent, while 79.1 percent is affected by various factors not examined in this study.

\section{Conclusion}

The research findings suggest many implications: mobile marketing has no obvious influence on impulsive purchase behavior. This demonstrates that greater usage of mobile marketing features does not always imply an increase in impulse purchasing behavior. Discounts appear to have little influence on impulsive purchases. This demonstrates that an increase in the amount of discounts available on specific items and at certain times does not necessarily translate into an increase in impulsive purchase behavior. Lifestyle variables significantly influence impulsive purchase behavior. This indicates that the more wealthier a consumer's lifestyle, the more prone they are to impulse purchases. The most critical indicator is one of client interest. All of these elements lead to an increase in impulsive purchase behavior, including mobile marketing, incentives, and lifestyle considerations. Mobile marketing, incentives, and lifestyle all have a cumulative effect of 20.9 percent on impulse purchasing. While the remaining 79.1 percent is governed by a variety of different factors.

\section{References}

[1] S. Kimiagari and N. S. A. Malafe, "The role of cognitive and affective responses in the relationship between internal and external stimuli on online impulse buying behavior," J. Retail. Consum. Serv., vol. 61, no. June 2020, p. 10-25, 2021, doi: 10.1016/j.jretconser.2021.102567.

[2] A. Lahath, N. A. Omar, M. H. Ali, M. L. Tseng, and Z. Yazid, "Exploring food waste during the COVID-19 pandemic among Malaysian consumers: The effect of social media, neuroticism, and impulse buying on food waste," Sustain. Prod. Consum., vol. 28, pp. 519-531, 2021, doi: 10.1016/j.spc.2021.06.008.

[3] M. Karl, P. M. Chien, and F. Ong, "Impulse buying behaviour in tourism: A new perspective," Ann. Tour. Res., vol. 90, no. 12, p. 103-136, 2021, doi: 10.1016/j.annals.2020.103136.

[4] I. Febrilia and A. Warokka, "Consumer traits and situational factors: Exploring the consumer's online impulse buying in the pandemic time," Soc. Sci. Humanit. Open, vol. 4, no. 1, p. 100-182, 2021, doi: 10.1016/j.ssaho.2021.100182.

[5] M. Leppäniemi, J. Sinisalo, and H. Karjaluoto, “A Review of Mobile Marketing Research,” Int. J. Mob. Mark., vol. 2, no. 1, pp. 30-42, 2006.

[6] C. C. Liang, A. P. I. Yu, and T. H. Le, "Customers focus and impulse buying at night markets," J. Retail. Consum. Serv., vol. 60, no. 168, p. 102-134, 2021, doi: 10.1016/j.jretconser.2020.102434.

[7] F. Yang, J. Tang, J. Men, and X. Zheng, "Consumer perceived value and impulse buying behavior on mobile commerce: The moderating effect of social influence," J. Retail. Consum. Serv., vol. 63, no. December 2020, p. 102-122, 2021, doi: 10.1016/j.jretconser.2021.102683.

[8] N. Bandyopadhyay, B. Sivakumaran, S. Patro, and R. S. Kumar, "Immediate or delayed! Whether various types of consumer sales promotions drive impulse buying?: An empirical investigation," J. Retail. Consum. Serv., vol. 61, no.1, p. 102-122, 2021, doi: 10.1016/j.jretconser.2021.102532. 
Huda et al / IJIIS vol. 4, no. 3, December 2021, pp 192-205

[9] S. Fu, X. Cheng, Y. Bao, A. Bilgihan, and F. Okumus, "Staying in a hotel or peer-to-peer accommodation sharing? A discrete choice experiment with online reviews and discount strategies," Internet Res., vol. 31, no. 2, pp. 654-676, 2021, doi: 10.1108/INTR-01-2020-0031.

[10] M. Belch, "Introduction to Advertising and Promotion : an Integrated Marketing Communications Perspective / MARK 301 Marketing Communications Course Outline,” Mark. Int. Bus., vol. 3, no. 4, pp. 1-18, 2006.

[11] T. Zhu, V. Singh, and M. D. Manuszak, "Market structure and competition in the retail discount industry," J. Mark. Res., vol. 46, no. 4, pp. 453-466, 2009, doi: 10.1509/jmkr.46.4.453.

[12] M. Mehta and R. Anand, "Social Media and Micro-Entrepreneurs: Lifestyle Marketing,” J. Entrep. Manag., vol. 1, no. 3, pp. 46-50, 2012

[13] K. Takakuwa, "Difficulties of Integrating Human Resources Management Globally by Japanese Corporations", Int. J. Appl. inf. Manag., vol. 1, no. 4, pp. 173-186, 2021.

[14]I. Phau and C. C. Lo, "Profiling fashion innovators. A study of self-concept, impulse buying and Internet purchase intent," J. Fash. Mark. Manag., vol. 8, no. 4, pp. 399-411, 2004, doi: 10.1108/13612020410559993.

[15]H. T. Du and N. X. Tho, "Purchasing Power Parity Between Vietnam and United States,” Int. J. Appl. Inf. Manag., vol. 2, no. 1, pp. 26-33, 2022.

[16]Z. Shah, “Permission-based mobile advertising,” J. Interact. Mark., vol. 16, no. 1, pp. 15-24, 2002.

[17]E. Bucht and R. Gillberg, "Mobile Marketing and its Effects on the Online Impulsive Purchasing Tendency," Technol. Soc. Sci., vol. 13, no. 3, pp. 34-88, 2015.

[18]E. J. Park, E. Y. Kim, and J. C. Forney, “A structural model of fashion-oriented impulse buying behavior,” J. Fash. Mark. Manag., vol. 10, no. 4, pp. 433-446, 2006, doi: 10.1108/13612020610701965.

[19]A. Weinstein, A. Maraz, M. D. Griffiths, M. Lejoyeux, and Z. Demetrovics, "Compulsive Buying-Features and Characteristics of Addiction," Neuropathol. Drug Addict. Subst. Misuse, vol. 3, no. January, pp. 993-1007, 2016, doi: 10.1016/B978-0-12-800634-4.00098-6.

[20]H. N. Do, W. Shih, and Q. A. Ha, "Effects of mobile augmented reality apps on impulse buying behavior: An investigation in the tourism field," Heliyon, vol. 6, no. 8, pp. 1-12, 2020, doi: 10.1016/j.heliyon.2020.e04667.

[21]X. Zheng, J. Men, F. Yang, and X. Gong, "Understanding impulse buying in mobile commerce: An investigation into hedonic and utilitarian browsing," Int. J. Inf. Manage., vol. 48, no. October 2018, pp. 151-160, 2019, doi: 10.1016/j.ijinfomgt.2019.02.010.

[22] L. Dukas, "Association between physical activity, fiber intake, and other lifestyle variables and constipation in a study of women,” Am. J. Gastroenterol., vol. 98, no. 8, pp. 1790-1796, 2003, doi: 10.1016/s0002-9270(03)00442-8.

[23]R. Wehrens, “Multivariate Regression,” Bus. Media New York, vol. 6, no. 1, pp. 149-185, 2013, doi: 10.1007/978-3-662-62027-4_8.

[24] D. C. K. P. Mahalakshmi, "An Exploration of Mobile Commerce and Its Impact of Consumer Buying Behaviour in the Digital Marketing,” Int. J. Adv. Innov. Res., vol. 6, no. 1, pp. 76-80, 2019.

[25] I. L. Wu, M. L. Chiu, and K. W. Chen, "Defining the determinants of online impulse buying through a shopping process of integrating perceived risk, expectation-confirmation model, and flow theory issues," Int. J. Inf. Manage., vol. 52, no. February, p. 102-128, 2020, doi: 10.1016/j.ijinfomgt.2020.102099.

[26] A. U. Zafar, J. Qiu, Y. Li, J. Wang, and M. Shahzad, “The impact of social media celebrities' posts and contextual interactions on impulse buying in social commerce," Comput. Human Behav., vol. 115, 2021, doi: 10.1016/j.chb.2019.106178.

[27] L. Zhang, Z. Shao, X. Li, and Y. Feng, "Gamification and online impulse buying: The moderating effect of gender and age," Int. J. Inf. Manage., vol. 61, no. January, p. 102-112, 2021, doi: 10.1016/j.ijinfomgt.2020.102267.

[28] C. A. Turkyilmaz, S. Erdem, and A. Uslu, "The Effects of Personality Traits and Website Quality on Online Impulse Buying," Procedia - Soc. Behav. Sci., vol. 175, pp. 98-105, 2015, doi: 10.1016/j.sbspro.2015.01.1179.

[29] J. Yeung, "Data Analytics Architectures for E-Commerce Platforms in Cloud,” Int. J. Appl. Inf. Manag., vol. 1, no. 1, pp. 1-5, 2021, doi: 10.47738/ijaim.v1i1.3.

[30] L. Wang, "Do consumers buy impulsively more often in mobile shopping than in store?," Bus. Law, vol. 8, no. 12, pp. 33-47, 2016. 
Huda et al / IJIIS vol. 4, no. 3, December 2021, pp 192-205

[31]D. Vazquez, X. Wu, B. Nguyen, A. Kent, A. Gutierrez, and T. Chen, "Investigating narrative involvement, parasocial interactions, and impulse buying behaviours within a second screen social commerce context," Int. J. Inf. Manage., vol. 53, no. April, p. 102135, 2020, doi: 10.1016/j.ijinfomgt.2020.102135.

[32] Y. M. Chen, “The Charisma of Online Group-Buying: The Moderating Role of Social Motivation,” IJIIS Int. J. Informatics Inf. Syst., vol. 2, no. 3, pp. 99-101, 2019, doi: 10.47738/ijiis.v2i1.86.

[33]E. (Christine) Sung and P. Huddleston, "Department vs discount retail store patronage: effects of self-image congruence," J. Consum. Mark., vol. 35, no. 1, pp. 64-78, 2018, doi: 10.1108/JCM-01-2016-1686.

[34] C. Parsad, S. Prashar, T. S. Vijay, and M. Kumar, "Do promotion and prevention focus influence impulse buying: The role of mood regulation, shopping values, and impulse buying tendency,” J. Retail. Consum. Serv., vol. 61, no. April 2020, p. 102554, 2021, doi: 10.1016/j.jretconser.2021.102554.

[35] S. R. Madhavaram and D. A. Laverie, "Exploring Impulse Purchasing on the Internet Exploring Impulse Purchasing on the Internet," Labovitz Sch. Bus. Econ., vol. 31, no. 31, pp. 59-66, 2004, [Online]. Available: http://www.acrwebsite.org/volumes/8849/volumes/v31/NA-31.

[36]H. N. Do, W. Shih, and Q. A. Ha, "Effects of mobile augmented reality apps on impulse buying behavior: An investigation in the tourism field," Heliyon, vol. 6, no. 8, pp. 1-12, 2020, doi: 10.1016/j.heliyon.2020.e04667.

[37]C. C. Chen and J. Y. Yao, "What drives impulse buying behaviors in a mobile auction? The perspective of the Stimulus-Organism-Response model," Telemat. Informatics, vol. 35, no. 5, pp. 1249-1262, 2018, doi: 10.1016/j.tele.2018.02.007.

[38] C. Li, Y. Wang, X. Lv, and H. Li, "To buy or not to buy? The effect of time scarcity and travel experience on tourists' impulse buying,” Ann. Tour. Res., vol. 86, no.12, p. 83-103, 2021, doi: 10.1016/j.annals.2020.103083.

[39]E. J. Lee, "The Effects of Internet Fashion Consumer's Impulse Buying Tendency on Positive and Negative Purchasing Behaviors,” J. Korean Soc. Cloth. Ind., vol. 13, no. 4, pp. 511-522, 2011, doi: 10.5805/ksci.2011.13.4.511.

[40] P. Guenzi, M. D. Johnson, and S. Castaldo, “A comprehensive model of customer trust in two retail stores,” J. Serv. Manag., vol. 20, no. 3, pp. 290-316, 2009, doi: 10.1108/09564230910964408. 